\title{
Competition Policy in Health Care in an ERA OF REFORM
}

\author{
Max Huffman ${ }^{1}$ \\ INTRODUCTION
}

Health care reform recently has been signed into law by President $\mathrm{Ob}-$ ama. The signing concluded a tortuous legislative process involving false starts, recriminations, accusations of stonewalling on one side and "ramming" using "dirty tricks" on the other, threats of filibuster, and fear of electoral response. ${ }^{2}$ Passage of health care reform legislation is just the beginning. As with all major legislation, there will be many years of learning what the new law means in application. ${ }^{3}$ And the absorption process for the second-order regulatory scheme of antitrust will be even slower. ${ }^{4}$ We in-

1. Associate Professor and Dean's Fellow, Indiana University School of Law - Indianapolis. For assistance and support in putting on the think-tank discussion and public panel to which this introduction relates, thanks to the Indiana University School of Law - Indianapolis, and especially Dean Gary Roberts; the Hall Center for Law and Health and its faculty co-directors Eleanor Kinney and David Orentlicher; staff at the School of Law, including Joanna MacDougall, Liz Allington, Shaun Ingram, Faith Knotts and Lauri Turner; and Heather McCabe and Carsandra Knight from the Hall Center. Thanks to Albert A. Foer, President of the American Antitrust Institute, and to AAI itself for their efforts in hatching this idea, moderating the public panel and bringing together an unparalleled group of experts for our day of meetings. Thanks to John Connor for originally proposing an event cosponsored by the IU School of Law - Indianapolis and AAI, and for his help and guidance in seeing it through to fruition. Thanks to Syd Arak, David Balto, Joe Bauer, William Comanor, Ted Frech, Tim Greaney, Cliff Johnson, Paul London, Emily Morris, Greg Pemberton, Gayle Reindl, Barak Richman and Chris Sagers for taking time from their schedules and giving so generously of their expertise. Further funding and support was provided by the office of IUPUI Vice-Chancellor Kody Varahramyan and IU Common Share. As usual, while the academics have their fun, the hard work falls to the students. Many thanks to $3 \mathrm{~L}$ students Brian Bouggy and Julie Mahomed of the IU School of Law - Indianapolis, and to the staff of the school's Health Law Review, for their extraordinary work in making the event and this publication a success.

2. See Ceci Connolly, "61 days from near-defeat to victory," Washington Post, Mar. 23, 2010, at A1, A6 (detailing the "twists and turns of President Obama's signature domestic issue" from summer 2009 through passage by partisan vote on March 21, 2010); Dana Milbank, "The Republicans who stirred the tea," Washington Post, Mar. 22, 2010, at A1, A11 (describing "one of the ugliest and strangest periods the American legislative process has ever experienced"); cf. Thomas Greaney, "Health Reform, a Class Act," Health Reform Watch Web Log, March 24, 2010, available at http://www.healthreformwatch.com/2010/ 03/24/health-reform-a-class-act/ (visited March 28, 2010) (noting "pseudo-journalism" and misinformation about health reform after its passage).

3. That is especially so because many provisions of the reform bill do not take effect for several years. See, e.g., Patient Protection and Affordable Care Act, H.R. 3590 (2018 effective date for tax on Cadillac Health Insurance Plans).

4. As a fundamentally common-law scheme, antitrust develops through court decisions over many years, such that even issues first decided nearly a century ago maintain remarkable currency. See, e.g., Leegin Creative Leather Prods., Inc. v. PSKS, Inc., 551 U.S. 877 (2007), overruling Dr. Miles Med. Co. v. John D. Park \& Sons Co., 220 U.S. 373 
troduce here the transcript of a panel discussion, held on December 10, 2009 , which we believe is the first broad (if not comprehensive) analysis of the competition policy implications of health care reform. These pages provide a road map for correctly analyzing many of the antitrust issues that have arisen in health care previously and are certain to arise in health care as reformed.

Understanding how to analyze these issues could not be more important. As panelist Paul London wrote in 2001, "[r]eal competition in health care would stimulate the American economy." London noted the competition picture raised questions about insurance, providers - doctors and hospitals, technologies and information systems, and regulatory approaches. ${ }^{6}$

To this end we convened a rare gathering of think-tankers, ${ }^{7}$ academic economists, ${ }^{8}$ law, business and medical school professors, ${ }^{9}$ and practitioners, ${ }^{10}$ all with deep expertise in the arenas of health law, antitrust law, and in many cases, both. Several of our participants came originally from the world of government antitrust enforcement. We gathered for an entire day, initially for several hours in a private think-tank style discussion, and later in a public panel discussion. During both sessions, topic leaders introduced a particular genus of issues on which they previously had submitted written work to the group. The topic leaders then described some possible resolutions to those issues, and the group engaged in the discussion. In the afternoon session, the transcript of which follows, we reprised some of the same discussion, but our public discussion was neatly distilled by the morning's conversation.

On December 10, 2009, the health care reform picture was uncertain. As Bert Foer said at our public panel held on that day, "when we set this up months ago, we didn't know whether there would be a law or not. And you know what? We still don't know -- which means between the House and the Senate and a conference committee that may or may not be joined, we don't know what this law is that we are talking about today." of Representatives had passed H.R. 3962, the "Affordable Health Care for

(1911). See also Max Huffman, A Retrospective on Twenty-Five Years of the Foreign Trade Antitrust Improvements Act, 44 Hous. L. Rev. 285, 289 (2007) (noting antitrust courts' experience in advancing doctrine through common-law analysis rather than statutory interpretation").

5. Paul A. London, The Competition Solution 187 (2001).

6. Id. at $190-95$.

7. Including Bert Foer, president of AAI, and David Balto, Senior Fellow, Center for American Progress.

8. Bill Comanor, UCLA and Ted Frech, UC Santa Barbara.

9. Joe Bauer, Notre Dame Law School; David Orentlicher, IU School of Law - Indianapolis, and adjunct professor, IU School of Medicine; Barak Richman, Duke University School of Law and Fuqua School of Business; Tim Greaney, Saint Louis University School of Law; Christopher Sagers, Cleveland-Marshall College of Law; Emily Morris, IU School of Law - Indianapolis; and Max Huffman, IU School of Law - Indianapolis.

10. Gayle Reindl, Taft, Stettinius \& Hollister LLP; Greg Pemberton, Ice Miller LLP; Cliff Johnson, Hall, Render, Killian, Heath \& Lyman PC; and Syd Arak.

11. Infra at 236. 
America Act," a month prior. ${ }^{12}$ Legislation stalled in the Senate - panelist Joe Bauer noted it was "sailing through the Congress, but ... at glacial speed," and at the time of our meeting, it was unclear whether health care reform would succeed at all, let alone in something resembling what Congress and the White House had been contemplating.

Meeting as we did with the reform picture uncertain might have seemed a risky proposition. "It might be that we are wasting our time and that there will be no law." 14 But such a concern arose only theoretically. When we originally discussed this project, we knew we might be discussing reform that would not happen this year. We also knew that health care reform of some sort was an eventual certainty, because the then-current system was not sustainable in the long run. And we know above all that the competition policy concerns that were the primary subject of our discussions transcended any particular time or legislative proposal.

This introduction introduces the substantive discussion that was transcribed during our afternoon public panel discussion. We divided our discussions roughly into four topics. First was the idea of health care reform from the perspective of the consumer of health care. Barak Richman served as our topic leader, and presented during both sessions (as did each of the topic chairs) on his analysis of the consumer of health services. Second, Chris Sagers discussed his writing on the health care insurance marketplace, with a particular emphasis on the possibility and implications of a repeal of the McCarran-Ferguson Act, at least as it relates to health care and medical malpractice insurance. ${ }^{15}$ David Balto discussed his analysis of the antitrust enforcement picture. Finally, Tim Greaney led the discussion about provider competition.

\section{THE THEN-EXTANT REFORM PICTURE}

Part of the process of discussing competition policy in health care reform necessarily was our developing an understanding of the reform picture that currently existed and was likely to emerge. David Orentlicher discussed the reform process, to the extent it was knowable on December 10. An important lesson from that introduction was the low probability that reform would meet the lofty hopes many had set for it. "I guess the interesting thing after hearing all the series of concerns that Barak has laid out nicely is how few of them are being addressed in the healthcare reform pro-

12. H.R. 3962, Nov. 7, 2009.

13. Infra at 263.

14. Infra at 236.

15. Sagers' written analysis is forthcoming in his essay, Much Ado about Probably Very Little: McCarran-Ferguson Repeal in the Pending Health Reform Legislation, 28 Yale L. \& Pol'y Rev. _ (forthcoming 2010), available at ssrn.com/abstract $=1546056$. 
posals." Orentlicher even suggested that one possible impact would be that by forcing new customers into a flawed system, the extent of its flaws would become untenable, and perhaps in the future, real reform might emerge. $^{17}$

That half-hearted optimism found support in others' remarks as well. William Comanor expressed disappointment that reform efforts threatened to "prop up the existing system of prepaid healthcare which is called Health Insurance but which isn't Health Insurance at all."18 Like Orentlicher, Comanor saw some possible benefit in a crisis in care, which might undo the "the rather bizarre way that we finance healthcare through the employment contract." Showing that approach was a vestige of the post-World War II era, he believed that system was self-destructing. ${ }^{19}$ And in a question-and-answer involving this author, Barak Richman discussed the economic impact of the influx of new consumers in the system. To the extent that insuring current uninsureds will increase their use of health care services, costs may well increase - once again leading to the possibility that reform as we have seen may be unsustainable in the long term. ${ }^{20}$

We heard about some of the different possible approaches to opening access to health care. One was the Veteran's Affairs Healthcare System, "the British system brought over to the U.S. . . It's not very convenient care, you might have to travel ... to get your care, but you'll get good care." 21 Another was the "German/Dutch/Massachusetts model. We make sure everybody is insured by requiring them to be insured." 22 In the case of the latter approach, insurance must be available if it is to be required. That entails making insurance available for the asking, including creating a marketplace "where insurance companies will have to meet certain qualifications and they can sell their plans .... [T] he government has screened and made sure these are plans that provide good quality coverage." The marketplace "hopefully will generate competition" and the consumer benefits that flow from it. ${ }^{23}$

The operation of the new insurance marketplace is an area of considerable uncertainty. The so-called insurance "exchange" exists to allow individual purchasers whose employer does not offer insurance to purchase it on their own. Purchasing on the exchange, in theory, those individuals will not suffer discrimination on the basis of pre-existing conditions and they will be able to afford insurance because prices will be lower and subsi-

16. Infra at 244 .

17. Id.

18. Infra at 261.

19. Id.

20. Infra at 271.

21. Infra at 244.

22. Id.

23. Infra at 246. 
dies will assist them. ${ }^{24}$

The driving features of the proposed reform that Orentlicher discussed included requirements imposed on individuals to become insured or pay a penalty; requirements imposed on employers to offer insurance; requirements placed on insurers to make insurance available; and subsidies provided by the government to decrease the costs of these requirements. ${ }^{25}$ Many variables threatened to undermine complete success in reform, if adopted as proposed. Not surprisingly, the most substantial of those was cost. Orentlicher noted the tendency of policy-makers to follow the approach of "expand[ing] access now, deal[ing] with costs later, but that doesn't always work, because it tends to unravel over time, becomes unaffordable. That was what happened when Oregon expanded its healthcare, they tried it, it worked for a few years and then, when they ran out of money .... When the economy turned, they couldn't afford to pay for the expanded access and their level of uninsureds is high as it was when they started."26

\section{THE CONSUMER}

One of the greatest difficulties in antitrust relates to what may be its most basic tenet. Antitrust law exists to protect consumers. ${ }^{27}$ That proposition appears to hold in every jurisdiction with an antitrust scheme. ${ }^{28}$ But what consumer protection means in antitrust remains poorly understood. ${ }^{29}$ Barak Richman argued the difficulty of defining the consumer protection role of competition policy is all the greater in the health care arena. ${ }^{30}$ That is not surprising. Health care consumer policy uncomfortably straddles the fence between pure consumer protection regulation and competition policy. I have recently argued that fence defines the line between enhancing and decreasing consumer choice. ${ }^{31}$ Requiring consumption of health services, on pain of penalty, is a measure that protects consumers even while undermining their freedom of choice.

The problem is exacerbated in part because "as we start thinking about consumers, what emerges is a multi-headed, multi-conflicted, multiincentivized entity that suffers from a great deal of confusion." ${ }^{32}$ Richman showed how consumers filled at least three capacities. One is the "consum-

24. Infra at 264-266.

25. Infra at $243-246$

26. Infra at 248.

27. Max Huffman, Bridging the Divide? Theories for Integrating Competition Law and Consumer Protection, 6 European Competition Journal 7, _ (2010).

28. Id.

29. Id. (citing sources).

30. Infra at 238.

31. Huffman, supra $\mathrm{n} .25$, at 10-11.

32. Infra at 238. 
er as a purchaser of insurance"; a second is "the consumer as the patient"; and the third is "the consumer as the voter." give rise to an irreconcilable tension: purchasers want cost low; patients want quality high; and voters prefer to limit subsidies.

Competition policy becomes very difficult where the consumer's direct interface is with the insurer, and the insurer interfaces (at least in terms of payment) with the provider. A monopoly provider market with a competitive insurer market threatens the circumstance that the consumer's voice with the provider is unable to protect the consumer's interests. Richman noted that theoretical and empirical evidence suggested the possibility that bilateral monopoly was better than diffuse insurers interfacing with concentrated providers. ${ }^{34}$ Competition in insurance presents another concern. It is possible "too many contracts would create information overload." 35 Richman also noted the problem of consumers being informed and given reasonable and understandable decisions. "[W]e're a long way from that." David Balto echoed that sentiment: "In terms of transparency, good luck!" These are problems in "creating some kind of vibrant market for health insurance." 36

The story is not much better in the provider marketplace, where consumers as patients do their shopping. The best providers - "the best price quality combination in America has generally been with these integrated systems like Kaiser or Mayo... where the insurer and the provider are the same entity" - are in "short supply."37 This reflects a poorly-functioning marketplace for "competition that would encourage consumers as patients to exercise their rights." ${ }^{38}$

\section{ANTITRUST IMMUNITY IN THE INSURANCE MARKETPLACE}

We also undertook a narrower focus on the exemption from federal antitrust regulation enjoyed by insurers under the McCarran-Ferguson Act. ${ }^{39}$ Repeal or partial repeal of the McCarran-Ferguson Act was intermittently part of the reform picture through 2009; as of our meeting on De-

\section{Infra at 239.}

34. Infra at 239.

35. Infra at 240. Cf. Remarks of Cavendish Elithorn, Fourth Antitrust Marathon, 6 European Competition Journal 1, 29 (2010) (noting the understanding of the UK Office of Fair Trading that "excessive choice can lead to less consumer activation in the markets and that is a source of detriment").

36. Infra at 240; id. at 251 (transcript 21) (Remarks of David Balto); cf. Edward J. Janger \& Susan Block-Lieb, Consumer Credit and Competition: The Puzzle of Competitive Credit Markets, 6 European Competition Journal 68, 71-72 (2010) (discussing the lemons equilibrium in competition in consumer mortgage lending flowing from lenders' competition on the opacity, rather than quality, of contract terms).

37. Infra at 241.

38. Infra at 242 .

39. 15 U.S.C. $\S \S 1011-15$. 
cember 10, it appeared most likely repeal would not be part of reform. In fact, McCarran-Ferguson repeal was not part of the health care bill signed by President Obama, although a free-standing effort to repeal the law, limited to health insurance (and not medical malpractice insurance) is pending in Congress as of this writing. ${ }^{40}$ McCarran-Ferguson immunity is not specific to health insurance, but the current "repeal effort . . . has been seen all along as part of healthcare reform." 41 The repeal was discussed only to "apply to carriers in health insurance and medical malpractice insurance," and "it might apply to only some of their conduct." 42

McCarran-Ferguson immunity came about in 1945, as Joe Bauer noted, in a bill signed by President Roosevelt not long before his death. ${ }^{43}$ Chris Sagers explained that, at the time of its enactment, immunity from antitrust was considered necessary on the basis of the economic theory of "destructive competition," applied to capital-intensive industries. 44 The exemption can also be justified if one has faith in the ability of states to regulate local industry effectively. ${ }^{45}$ Experience undermined the story of the states as effective regulators of insurance - "probably one of the saddest parts of McCarran-Ferguson is that the amount of regulation by the states necessary to enjoy that exemption has been minimal." session, we discussed seemingly overt circumstances of the state insurance commissioner position being a political spoil for campaign donors. The result is inadequate regulation by the states, and, as Sagers noted, "there doesn't seem to be much doubt that in health insurance we don't have a competitive marketplace at all." ${ }^{, 47}$

Whether repeal could be effective is another story. As of our discussion on December 10, repeal efforts tended to be targeted at specific categories of egregiously anticompetitive conduct - price fixing, bid rigging and market allocation - which arguably are outside the statutory exemption for the "business of insurance," and therefore illegal even under McCarranFerguson. ${ }^{48}$ Also, repeal would take place in highly concentrated markets,

40. Health Insurance Industry Fair Competition Act, H.R. 4626, 111 th Cong., 2d Sess. (Feb. 22, 2010).

41. Infra at 250.

42. Chris Sagers, Much Ado About Probably Pretty Little: McCarran-Ferguson Repeal in the Pending Health Reform Legislation, 28 Yale Law \& Pol'y Rev. _ (forthcoming 2010 ), draft at 1 , available at ssrn.com/abstract $=1546056$.

43. Infra at $249 ;$ id. at 260 ,

44. Sagers, supra n.42, at _(draft at 5). That theory has been largely debunked since 1945. See id. at 7; $c f$. Daniel H. Cole \& Peter Z. Grossman, Principles of Law and Economics 306 (2005) (questioning the reality of natural monopoly).

45. $C f$. id. at 6 (noting "trends" that "had already led to rate-and-entry regulation in markets throughout the U.S. economy").

46. Infra at 263; see also Sagers, supra n.42, at _ (draft at 8-9) (regulation sufficient for McCarran-Ferguson Act purposes if there was "some regime of state oversight," even if not fully effective).

47. Infra at 249; id. at 250-251; see Sagers, supra n.42, at 11-12.

48. Infra at 249-252; $i d$. at 261. The pending McCarran-Ferguson repealer legislation 
where it seems unlikely competition would immediately take hold. Sagers argued repeal would be a salutary phenomenon in any event. In the long term, competitive conditions might arise, and having repealed the exemption, even if only narrowly, would help that competition to flourish. Sagers also noted the important signaling value of repeal, which would be "a pretty strong message to the Justice Department or the Federal Trade Commission to actually do something." 49

\section{ENFORCEMENT}

The discussion of antitrust enforcement was largely pessimistic, although, as David Balto noted, "[c]ompetition and consumer protection enforcement is important, because we want markets to work effectively . ... $[N]$ o one has so far disagreed with me on this diverse panel ...."50 In the case of health insurance, Balto and Sagers both noted the high level of concentration in the industry, where "[o]ver 400 mergers in the past eight years ... has led to this tremendous degree of concentration." ${ }^{\text {" With re- }}$ gard to insurance, it is, of course, impossible to uncouple concerns for anticompetitive behavior from the antitrust exemption for insurance under the McCarran-Ferguson Act. Immunity was therefore an important part of our conversation. $^{52}$

In addition to competitive concerns in health insurance, Balto noted the role of consumer protection regulation. Concerns for conflicts of interest arise, because insurers ostensibly representing patient interests have incentives to limit care that might be in those patients' best interest. Health insurers may be engaged in fraudulent conduct, but Federal Trade Commission resources are devoted to "fraudulent advertisers who tell you that if you take this pill, you'll lose 20 pounds over the next week." States lack the resources to enforce either antitrust or consumer protection prohibitions against the insurance industry - "over a third of all states have never brought a single consumer protection action against fraudulent or deceptive activity by health insurance companies and something like $95 \%$ of the actions were brought by just four states."53 Finally, Balto cited the FTC's "secret weapon" - Section 5 of the FTC Act, which gives that agency an

is not so limited. See H.R. 4626 (2010).

49. Infra at 252.

50. Infra at 253.

51. Infra at 254; id. at 249 ; see also Sagers, supra n.42, at 11-12 (noting 400 mergers "in the past 14 years") (citing, inter alia, Am. Med. Ass'n, Competition in Health Insurance: A Comprehensive Study of U.S. Markets, 2007 Update (2007)). The concentration concern implicates Barak Richman's comments about the possibility that a bilateral monopoly is preferable to a concentrated provider market and a competitive insurance market. See supra nn. _- a a a d accompanying text.

52. See infra $\mathrm{nn}$. - - and accompanying text; infra at 246-250.

53. Infra at 255. 
ostensibly broader mandate than the antitrust laws. ${ }^{54}$

Gayle Reindl noted, and discussion during our day program supported the point, that the FTC has been quite active in one area of health care antitrust, which is that having to do with so-called pay for delay settlements between brand-name and generic pharmaceutical manufacturers. ${ }^{55}$ Those settlements have the effect of splitting the profits from the monopoly the brand-name manufacturer is able to preserve by paying the generic to delay entry into the market in competition with the brand-name drug. It is the courts, not the FTC, that have held up enforcement in that arena.

Reindl's comment makes an important point: even a highly reinvigorated enforcement regime must contend with a judiciary that may be hostile to antitrust enforcement. ${ }^{56}$ Tim Greaney noted that case law has not been friendly to a vigorous enforcement agenda against such abuses. ${ }^{57}$ Chris Sagers, during a question-and-answer colloquy, went further: "my sense is there has evolved very quietly a case law for healthcare, and particularly for hospitals, that is in a lot of ways special. It's not a statutory exemption, obviously, but it is arguably a judicial one."58 Except for a class of cases that are in reality tort, contract or employment claims by doctors against hospitals, ${ }^{59}$ other health-care antitrust case law threatens to limit enforcement against anticompetitive conduct by providers.

AAI recently has carefully examined the question of antitrust enforcement in health care. In Competition in the Unhealthy Health Sector, one chapter in AAI's Transition Report on Competition Policy, ${ }^{60} \mathrm{AAI}$ made recommendations with regard to healthcare intermediaries, pharmaceuticals, providers - including physicians and hospitals, and government involvement - both regulatory and with regard to the government as a market participant. The upshot of the AAI recommendations, which was echoed broadly during our meetings on December 10, is the need for "[g]reater resources" to "be devoted to health care antitrust enforcement."61

\section{PROVIDER COMPETITION}

Tim Greaney led the discussion of provider competition with the observation that among hospitals, doctors and pharmaceutical manufacturers,

54. Infra at 256.

55. Infra at 260.

56. See also infra at 270 (citing Bell Atlantic Corp. v. Twombly, 550 U.S. 544 (2007), and American Needle v. NFL, S. Ct. No. 08-861 (argued Jan. 13, 2010)).

57. Infra at 259.

58. Infra at 270 .

59. Greaney referred to these cases as "the junk food of antitrust" and applauded the decisions dismissing many of them. Id.

60. American Antitrust Institute, Transition Report on Competition Policy 317-48 (2008), available at www.antitrustinstitute.org.

61. Id. at 321. 
"competition does matter.... [W]e do have evidence that the competition has lowered cost." ${ }^{\prime 62}$ The corollary point is, of course, the impact of a lack of competition on costs. "[H] ospital mergers ... have raise costs from 5$40 \%$ in the markets in which they have occurred.,

But Greaney also noted the tension between concentration and "fragmentation." In the case of the latter, physicians practice either solo or in small groups, so "there's very little care coordination." The solution to the latter appears to be vertical integration, whereby physicians, nurses, social workers, alternative care providers and hospitals coordinate care efforts. That kind of bundling can be tremendously good for care, as Barak Richman had noted earlier with regard to the famous success stories of integrated providers Kaiser and Mayo. ${ }^{64}$ The AAI, in its transition report, echoed Greaney's view of the value of "efficiency-enhancing integration where the result is more cost-effective, higher-quality delivery of care." $" 65$

In addition to increased concentration, Greaney noted the ability of an "entity with market power [to] exclude others." of dominance underlay much of the discussion on December 10. Examples of abuses of dominant positions arise in hospital marketplaces. Those may include raising rivals' costs, with the impact of limiting competition. Tying arrangements that leverage market power into other markets may permit hospitals to avoid limits on Medicare reimbursements. And hospitals have incentives to limit competition by physician-controlled specialty hospitals. ${ }^{67}$

Finally, concerted activities by providers that do not serve to benefit consumers through efficiency-enhancing integration continue to present concerns. "An examination of cases brought over the last thirty years reveals that ... overt cartelization schemes [involving physicians] have not disappeared and in fact may have increased in recent years. ${ }^{168}$ It is thus necessary, AAI says, to ensure "sufficient sanctions to deter future wrongdoing." 69

The foregoing serves only to provide a short summary of the discussion on December 10, 2009. The following pages comprise the transcript of the public panel discussion held that day.

62. Infra at 257.

63. Id.

64. Infra at 241 ; see supra $\mathrm{nn}$. _- and accompanying text.

65. Transition Report, supra $\mathrm{n} . \overline{47}, \overline{\text { at }} 340-41$.

66. Infra at 258. See generally Jefferson Parish Hosp. v. Hyde, 466 U.S. 2 (1984).

67. Transition Report, supra n.60, at 343.

68. Transition Report, supra n. 60, at 340 (citing Thomas L. Greaney, Thirty Years of Solicitude: Antitrust Law and Physician Cartels, 7 Hous. J. Health L. \& Pol'y 189 (2007)).

69. Id. at 341. 


\section{HEALTH LAW ROUNDTABLE EVENT -COMPETITION POLICY IN HEALTH CARE IN AN ERA OF REFORM, DECEMBER 10, 2009, INDIANA UNIVERSITY SCHOOL OF LAW - INDIANAPOLIS}

DEAN GARY ROBERTS: Good afternoon everybody. Welcome. I am Gary Roberts, I am the Dean of the Indiana University School of Law -Indianapolis, and I am here today to introduce and welcome you to this tremendous program we have put together.

The School of Law and the Hall Center for Law and Health, which is one of the signature centers on campus, has partnered with the American Antitrust Institute, a Washington D.C.-based think-tank. In recent years AAI has been a leader in advocating for more aggressive antitrust enforcement.

We are also gratified to have received some financial support for the program from the campus office of Vice Chancellor Kody Varahramyan and also the IUPUI endowment fund. We thank them for their support.

Our speakers today are some of the nation's leading experts on the intersection of health policy and antitrust, and they hail from the law faculties, economics faculties, think-tanks, and private law practice. And they spent almost the entire day up to now in a private, closed-door session, brainstorming about different ideas, and I have been told it was a robust and exciting conversation.

I want to turn this over to the moderator of today's panel, Albert Foer. $\mathrm{He}$ is the President of the American Antitrust Institute. Bert's varied career has included private law practice in Washington, DC with Hogan \& Hartson and Jackson \& Campbell; the Federal Senior Executive Service as an Assistant Director and Acting Deputy Director for the Federal Trade Commission's Bureau of Competition.

He's been the CEO of a mid-sized chain of retail jewelry stores. He has also been a prolific author, publishing numerous articles and book chapters. He is a graduate of the University of Chicago Law School, did his undergraduate degree at Brandeis, and he also has a masters degree from Washington University. Let me turn this over to Bert.

MR. FOER: Thank you Dean Roberts and thank you to the Indiana University School of Law - Indianapolis, and particularly to Max Huffman, professor at the law school who organized this event. As I think you are going to see -- it took a little bit of guts to put this program together because 
it's pretty experimental.

The American Antitrust Institute is an 11-year-old think-tank in Washington. We do education, research, and advocacy functions. And we sometimes do brainstorming, trying to figure out what the right questions are to be asking about a topic. That's what we did this morning. We spent about four-and-half hours of this group and a few people who are still here and a few people who've already left.

We have been talking about healthcare reform. Now, when we set this up months ago, we didn't know whether there would be a law or not. And you know what? We still don't know -- which means between the House and the Senate and a conference committee that may or may not be joined, we don't know what this law is that we are talking about today.

It may be that we are wasting our time that there will be no law. Even if there is no new law at this time, however, there are going to be very significant competition issues that will continue to be relevant and there is no better group than the people sitting here to discuss those issues, to try to pinpoint where the issues are, not necessarily solve any of them but at least help us identify the key issues that we think you should be looking at.

Let me say also that some members of the panel are going to have to catch planes before we finish so don't worry if they are walking out, it does not necessarily mean they disagree strenuously with everything they've heard. If I start at my far right -- where he doesn't belong politically -- is Bill Comanor from the University of California, Los Angeles, and Santa Barbara. Bill is an economist and a former Chief Economist of the Federal Trade Commission.

David Balto is a senior fellow at the Center for American Progress, and he was the Policy Director of the Bureau of Competition at the FTC, and the Attorney Advisor to Chairman Robert Pitofsky for a number of years. He is one of the most brilliant and sometimes outspoken experts in the field of competition policy. If we don't get a chance to hear much from him, it's a loss for everyone here.

Chris Sagers is a Professor at Cleveland-Marshall College of Law where he teaches Antitrust and Administrative Law. Chris is a new member of the AAI Advisory Board.

David Balto, by the way, and Bill Comanor are both members of the Advisory Board, and Joe Bauer from Notre Dame, as well. Joe is a real expert in the field of antitrust. $\mathrm{He}$ is the author of a major treatise on the subject, comes to us today from up the road in South Bend. 
Now David Orentlicher is your homegrown twofer - a lawyer and a doctor. He is Professor of Law and Co-Director of the Hall Center for Law and Health at the IU School of Law -- Indianapolis, and an adjunct professor at Indiana University School of Medicine. Terrific background for this discussion.

Next is Barak Richman, another and fairly new member of the AAI advisory board. He is Professor of Law and Business Administration at Duke University. He teaches Antitrust and Healthcare Policy. He is the CoEditor of the symposium volume of Law and Contemporary Problems with Clark Havighurst which was entitled "Who Pays? Who Benefits? Distributional Issues in Health Care."

And then we have Thomas "Tim" Greaney, a member of our Advisory Board. Tim is a Professor at St. Louis University. He is the Charles A. Meyers Professor of Law and Director of the Center for Health Law Studies at St. Louis University, and the author of one of the nations leading health law casebooks, as well as a treatise and hornbook on health law.

Gayle Reindl is local, she is a litigation partner at Taft Stettinius and Hollister LLP, where she does antitrust litigation and some healthcare litigation.

And finally we have Paul London. Paul is an economist, a consulting economist and the author of a book called 'The Competition Solution'. Back in the Clinton administration he was the Deputy Under Secretary of Commerce for Economics and Statistics.

That's your group. What we are going to do is start out with Barak Richman talking from the point of view of the consumer. In this healthcare reform, where does the consumer fit into the picture?

He will be followed by David Orentlicher who is going to give us an overview of the reform legislation as it stands and as it may be moving along even as we sit here talking. That will be followed by Chris Sagers who will talk about one of the more direct antitrust issues namely the McCarran-Ferguson Act which helps to structure the relationship between the insurance industry and the antitrust laws.

Then we'll turn to Tim Greaney. Tim will focus in more on competition implications over and above the McCarran-Ferguson Act. At that point in time we will have some discussion among the members of the panel and time permitting then we'll invite questions from the audience. 
and thank you to Indiana University. You can tell that I am from one of the right coast here. It's a great pleasure to be here.

So it's my job -- I guess it's really the job of all the speakers -- to summarize the thoughts of a particular segment of the discussion that the AAI organized this morning.

The segment of discussion that I am summarizing focused on the question of how healthcare reform and healthcare reform efforts -- and particularly competition law in healthcare reform - should be approached from the perspective of consumers?

The way that we first have to approach this problem is to ask, well, who exactly are the consumers? And as we start thinking about consumers, what emerges is a multi-headed, multi-conflicted, multi-incentivized entity that suffers from a great deal of confusion.

One might think we are talking about the consumer who is a potential purchaser of health insurance, but who currently is uninsured either because they cannot purchase health insurance themselves, because it's so expensive, or because they are working for a small business who itself cannot afford health insurance.

Alternatively, we might be referring to the consumer who really became notorious and very popular about ten years ago, the consumer who has purchased health insurance, and is now a subscriber to an HMO, but who complains about waits to see doctors, excessive monitoring by insurance bureaucrats, and the mean people on the telephone who deny routine coverage.

Are we talking about the consumer that cannot afford health insurance now or are we talking about the consumer who didn't like the inexpensive insurance they had before?

Now, of course, this person is the same person and having low-quality insurance but being able to purchase it is the flip side of the same coin as not being able to afford it now. But we don't think of these two consumers as the same person. We think of these two consumers as expressing legitimate consumer-oriented concerns without any hint of irony, without a recognition that in fact the better health insurance gets the more expensive it's going to be. The nicer they are on the telephone the more comprehensive the benefits are, the more expensive the premiums are and fewer of you will be able to afford it.

That fairly obvious observation needs to be (but so far has not been) 
part of the healthcare reform discussion, and the irony should not be lost on us. When we think about consumer interests, we are necessarily thinking about market trade-offs.

So within that lens of consumer trade-offs, and the realistic trade-offs that arise in the marketplace in the provision of any good in a competitive marketplace, we want to think about consumers from three perspectives: the consumer I was talking about a moment ago, the consumer as a purchaser of insurance; the consumer as the patient; and the consumer as the voter.

How do we think about all three of these individuals? And how do we think about healthcare reform issues from their perspectives? How can reform advance the interests of these three consumers? Since we all identify with consumers, we think that if we pursue consumer interests, we will not only be promoting competition but we also will be pursuing good policy. We think that if we somehow get the consumer what the consumer wants, we will achieve socially desirable outcomes.

How do we think about ways to enact reform that would advance the interests of the consumer, because after all, all of us consider ourselves as consumers, all of us identify with consumers, we might identify, well, the consumer that we think is less confusing than the one I just described, but we think that if we pursue consumer interests, we will not only be pursuing competition but we also be pursuing good policy, will have social desirable outcomes, if somehow or another we get the consumer what the consumer wants.

Let's begin with the consumer as health insurance purchaser. What interests are there when we think about the consumer as a person of health insurance? Well, certainly we want the consumer to have a variety of choices in the marketplace for health insurance. We think that competition is a good thing, and if the purchasers of insurance have more choices then providers of health insurance have to compete with each other, and more competition ceteris paribus is a good thing. Accordingly, much of the discussion on Capitol Hill has been really focused on this issue: how do we make sure the purchaser of health insurance has more choices?

There are a couple of qualifications to that though. One is, what happens if you have a highly-concentrated provider market? That is, you have doctors and hospitals that dictate their prices because there are not hospitals or alternative providers down the road that offer competitive alternatives. Actually there is a hospital down the road that used to be able to compete, but those two hospitals have since merged. And there are lots of doctors in town but they all talk with each other and they all come up with price agreements and thus all set the same price. Lack of competition among pro- 
viders is a very significant problem.

So what happens if you have essentially a monopolized provider market? Is it then good to have lots of small insurers or do you actually perhaps want one big insurer that could really negotiate price discount from the providers?

The answer is, we don't know. We just don't know what is better. In fact, I think a better way to characterize the literature of economic models and very limited empirical evidence is that it might be better to have a bilateral monopoly than to have an upstream monopoly of providers and a competitive insurance market downstream, but we don't know.

So is competition among the health insurers better, ceteris paribus, even without doing anything about the lack of competition among providers? We don't know the answer to that.

Another thing to consider is that these are incredibly complicated insurance products. When you buy insurance you are really signing a very complicated and detailed contract. Those of you in the world of law know that the market for insurance is really a market for contracts. And markets for contracts usually produce enormous complexity, specificity, terms that are difficult to read, and terms that people don't read.

So do you want more competition in that market, ceteris paribus, given the complexity? The answer to that also is we don't know. There might be very good reasons to have some competition, so the market offers more than one contract, but perhaps too many contracts creates information overload and consumers just wouldn't make informed decisions or perhaps won't make any decisions at all. And if we want useful competition, we need to empower consumers who purchase health insurance to make informed decisions. We need to make the options available to them reasonable, understandable, and comparable to each other.

But we're a long way from that. When we think about creating some kind of vibrant market for health insurance, these are things we have to think about. We have to think about the consumer that we have.

What about the consumer as patient? You would think the consumer as patient would, like a consumer of cars (or like any kind of consumer), want the best mix of price and quality.

When we purchase cars, the quality generally increases with price. Generally, not always, but generally quality correlates with price, and all of us decide where along this price quality continuum we want to be. We have 
a certain amount of money, we want to get good quality, we decide what to do, but we make these trade-offs, these price quality trade-offs when we purchase things.

You would think that the consumer as patient would make those same decisions -- they want good healthcare at a low cost. Well, as a preliminary observation, the best price quality combination in America has generally been with vertically integrated delivery systems like Kaiser and Mayo, where the insurer and the provider are either the same entity or are contractually intimately integrated with each other.

We have to figure out why -- this is a million dollar question or a $\$ 2$ trillion question -- why is it that the best delivery system out there is in such short supply? Why can't we replicate Kaiser and Mayo, which are renowned for providing excellent quality care at below average prices, and let them proliferate in all of America's healthcare markets? Why don't market forces yield a deserving winner, like they do for most other products and services markets?

In a market economy that prides itself on competition, it is unacceptable that the market's superior options are largely denied to the consumer as patient. Thus, we have to think about how we can significantly reorganize the delivery system -- much more so than the insurance system -- to figure out how we can make those choices available to the consumer as patient.

What are the reasons market forces are failing so miserably in this market? Perhaps we should ask the very preliminary question, what do consumers-as-patients choose? If you listen to the political rhetoric, you are told that consumers insist on the right to choose their own doctor; they insist they have a right to certain healthcare services; and they further claim they have a right to exert their freedom of choice. They accordingly demand these freedoms and services from their insurance companies.

One priority you do not routinely hear from patients is the importance of economizing, of trying to save money on healthcare. And there is a reason for that. Most patients, people who have health insurance, do not know how much they are paying for health insurance. Their health premiums are being taken out of their paycheck by their employer, because their employer pays for health insurance and the employee, the employee-as-consumer, doesn't know how much that is.

In fact, if you actually ask someone who is making $\$ 40,000$ a year and say, do you want to spend what amounts to a quarter of your total income on health insurance, clearly most will prefer to economize? But they are unaware that $\$ 10,000$ of their annual income is going towards their health 
benefits. So instead you have patients who do not know how much they are paying, and instead only make choices based on quality to the degree they can observe quality. And we have consumers-as-patients saying, I demand to choose my own doctor. I demand to get whatever services I want. I am entitled to these and there is no cost-benefit, there is no cost-quality tradeoff being made.

So the decisions that are being presented to the consumers-as-patients are quite dysfunctional. Perhaps it shouldn't be surprising that we and we do not have an effective marketplace for competition that would encourage consumers-as-patients to force competition on the provider market.

What about consumers-as-voters? Consumers as voters are exceptionally good consumers. They are very loud. They make their voices known. Healthcare is a very emotional, very sensitive topic. It mobilizes a lot of political activity. Consumers as voters are very, very good consumers.

The only thing is they don't really think about that cost-quality tradeoff. For example, about in the current healthcare debate has been overwhelmingly demanded by consumers? Perhaps there are two kinds of consumers: those to the right and those to the left. In political debates, when consumers act as voters, we see a bifurcated market. The country unfortunately is very much divided in half and the consumers as voters reflect that.

What do consumers on the right say? Consumers on the right say, we don't want government in our healthcare at all. Of course, that neglects the role of Medicare, it neglects the federal role of investing in research, it neglects the role of governmental quality assurance, providing courts to resolve disputes, governments providing training for medical residents, military medicine, and many other public health services. The government is heavily involved with lots of things that consumers to the right like and want to keep.

What do consumers on the left say? Consumers on the left also happen to like Medicare. They like the fact that Medicare is so comprehensive, and they like the fact that Medicare does not manage their consumption at all. Medicare lets them take what they want, and co-payments are relatively affordable. Consumers on the left say, this is great! Government organized, government paid-for insurance is perfect. This is what we want, we should expand it. And in fact, one of the compromise proposals is to expand Medicare to individuals between 55 and 65 .

But of course, Medicare is going bankrupt. We can't afford Medicare and the reason the overhead costs are so low is because it's unmanaged. 
That means Medicare invites over-consumption, is vulnerable to fraud, and does not seek opportunities to economize. Even though the consumer loves it, do the consumers realize how expensive it is? One economist in our discussions said, if you were offered Medicare as an insurance option, you would never take it, because it doesn't direct you to make the right decisions. It's overwhelmingly expensive. We don't know this because really our grandchildren are going to be paying for us.

The fact there Medicare exhibits low overhead probably suggests it should have a higher overhead. Tell that to the consumer as the voter. Medicare is often the third rail -- or the fourth rail, since Social Security is the third rail - of politics, and the consumer-as-voter approaches this as a rights question, not as a question involving limited resources in which the current situation is driving the country bankrupt.

So for the consumer-as-insurance purchaser, we have to make sure the market works so that consumer is incentivized to make responsible decisions and encourages insurers to provide products that consumers demand. Currently it's not that way. The consumer-as-patient currently isn't afforded the options that a market economy should provide. Instead, the consumeras-patient is not exposed to the costs of his or her decisions - and often also cannot observe the quality of his or her decisions - and thus many consumer-as-patient decisions are misguided and exacerbate the system's current problems.

And the consumer-as-voter is speaking out of ideology and is not speaking out of commonsense practicality. So if we want consumers involved on any of these levels, we cannot heed consumers that are inconsistent, uninformed, or rash. We instead need consumers who think comprehensively, who recognize that, for example, typical voters make demands that hurt typical insurance purchasers, or who recognize that the needs of insurance purchasers are in tension with the demands of patients. A consumer who thinks comprehensively is more likely to act responsibly, instead of driving toward choices that push costs on other people.

MR. FOER: Thank you, Barak. That's something I always wanted to say. Thank you, Barak! Now David Orentlicher is going to tell us how the other Barack and his friends on the Hill are going to fix things.

PROFESSOR ORENTLICHER: Well, thank you! I guess the interesting thing after hearing all the series of concerns that Barak has laid out nicely is how few of them are being addressed in the healthcare reform proposals. That's really the sad thing about it all. I'm all for healthcare reform, but the way I put it, rather than trying to fix a flawed system--you've heard of the many flaws it has--what we're really trying to do is put more people 
into the flawed system and hope that down the road that will create enough voter support for fixing the flawed system.

But when you look through the thousands of pages, there is discussion but in terms of real impact on the flaws, there really is not much there. So what are we doing? The goal is to cover the uninsured. We've got $15 \%$ of our population, 47 million--it's probably higher because the data will haven't caught up with the recession--in the range of 50 million uninsured. So how do we get there?

Some of us have wanted some sort of single system where everybody gets health care, whether it's a Medicare-for-all or getting back to some of the models out there. Barak identified some good ones, but maybe the best model out there is the VA Healthcare System.

If you want a low-cost high-quality system - it turns out the British system brought over the U.S. in the form of the VA Healthcare System, is that kind of system. If you are a qualified veteran--not all veterans are eligible--but veterans go to hospitals operated by the U.S. government, doctors employed by the U.S. government and you get high-quality low-cost care. It's not very convenient care--you might have to travel a ways to get your care--but you'll get good care.

But it has never been on the table to have VA for everybody or Medicare for everybody. But how else do we get everybody into the health care system? What's another important model out there? It's the German/Dutch/Massachusetts model. We make sure everybody is insured by requiring them to buy insurance.

And this is kind of an American approach. We believe in individual responsibility. If we think back to the patient as voter, what we find is that patients as voters don't very much like government benefits that are viewed as handouts. In the US, you've got to earn your benefits. You've got to be a "deserving" recipient. I put this in quotes--please don't think that this is my view--I'm caricaturing and not everybody takes this view, but it's a strong sentiment in America that you should be a deserving of your government benefits. So we have good healthcare for seniors who have earned it because they've worked hard all their lives and they've gotten to a point where their age is overtaking them and they are sick not because they've acted irresponsibly but because that's the nature of aging. They don't have the money to buy insurance because they are retired, so we cover them. We cover children because how can you hold children responsible for not having healthcare, that's not reasonable. 
we give you healthcare insurance, you probably won't work because why would you if you get everything for free. So it's an American approach, and so we're going to require you to buy insurance.

If you can afford it, you ought to get it on your own. So there is an individual mandate to purchase insurance in the House and Senate bills, with exemptions for the lower-income persons and there will be subsidies for other people. You are working, but may be you are employed in a job that only pays $\$ 40,000$ or 50,000 . Can we really ask you to spend $25 \%$ of your income on healthcare insurance? That's not realistic. So there will be subsidies that phase out at $\$ 88,000$ income; that's what's on the table now.

Well, why would you buy an insurance if you don't have it now--there must be reasons why you haven't bought it--and if it's still very costly, why would you buy it? Well, we'll penalize you if you don't. There are fines that will amount to in the Senate bill about $\$ 750$ per person and in the House bill, it's a percentage of income. But let's say, you are a single person earning $\$ 60,000$. Under the House bill, you would have to pay, about $\$ 1000$ in penalty.

So if you are earning $\$ 60,000$ and you have to go out and buy insurance and it might cost you $\$ 6,000$ or $\$ 7,000$, and the penalty is only a $\$ 1000$, you still may not buy it. So this is one reason why even with the mandate, we are not going to get to universal health care coverage.

There's another way to help cover the uninsured. Who else has some responsibility under the House and Senate bills? Employers. Even though employer-based insurance has problems--as Barak says, we don't really know how much we're spending on health care coverage. Indiana University is kind enough to tell its employees. If we look at our pay stub, it tells us how much of our salary IU is spending. But we never get the money. So we don't feel like it's our money. We feel like it's their money that they are using for us rather than taking it out of our paycheck. But they really are taking it from our pay.

Both the House and Senate have kind of employer mandates. Under the House bill, employers either provide insurance or they will pay an $8 \%$ payroll tax. So whatever your payroll, multiplied by $8 \%$, which is a pretty good incentive to provide insurance.

The Senate doesn't say you have to provide insurance, but if you have at least one employee who gets a government subsidy to buy insurance-because you are not providing coverage, so the government has to subsidize--then we are going to charge you $\$ 750$ an employee. That's the incentive to provide health care insurance. But the House has a stronger incentive 
than the Senate.

What else? Insurers. If people have to purchase insurance, insurers have no reason to do actuarial screening and decide whether to offer coverage. If you don't have to buy insurance and if insurers had to provide you coverage, you'd wait until you are sick. Why buy coverage when you are healthy? Many people would say, "I'll wait till I am sick." But that's not fair to insurers. If you have to buy insurance, then we can say to insurers, you have to take all comers. You can't reject somebody, because they have preexisting medical problem. Say they've got diabetes or heart disease. You can't refuse to cover them, you can't charge them a higher premium.

That's an important protection for the people who don't have an employer who provides insurance. Their inability to buy coverage, because of preexisting condition, this will take care of that. That's a very important part of the health care legislation. In addition, there will be no more lifetime caps on coverage. Most people have $\$ 1$ million, $\$ 3$ million, $\$ 5$ million dollar cap lifetime. Those caps will be eliminated.

Well, where will you get insurance if you now have this burden to buy it? If you don't work at IU or Lilly, and get your insurance, you have to go and buy it. Where will you buy it? The government will set up insurance exchanges, either nationwide under the House bill or state-based under the Senate bill, where insurance companies will have to meet certain qualifications to sell their plans. Massachusetts has set up a similar kind of program under its mandate to buy insurance. So you can go and shop, and the government has screened and made sure these are plans that provide good quality coverage. So there will be a marketplace that hopefully will generate competition, and you'll buy your insurance there.

What about the very poor people? There are limits on how much we can subsidize health care premiums. Medicaid will be expanded to cover people. In the Senate bill, Medicaid will cover people up to $133 \%$ of the federal poverty level. What does that mean? For a single person, it is probably in the range of $\$ 13,000$ or $\$ 14,000$ income. Anybody below that level will be under Medicaid. If you are a family of four, and you earn less than $\$ 30,000$, you would qualify for Medicaid.

Not everybody will be insured-we'll get into the $93,94,95 \%$ range according to projections. This, then, is the expanding access part.

How we are going to pay for this expanded access? It's not going to be free. Although, it could be in some ways, because we do spend far more than every other country. This is one of the paradoxes. We spend more and get less. All these other countries reach all of their population and spend 
less -- many of them spend half or less of what we spend.

So in some ways we have the money to cover more people. But there are a lot of inefficiencies that we are not addressing - and that's the problem we are not addressing. Why do we have such high cost? Why aren't there more Kaisers? Why aren't there VA-kind of systems all over the country? Well, we are not addressing that, we are not trying to replicate the low-cost high-quality systems. So it's going to cost us more money to expand access.

Now remember President Obama said, he is not going to tax anybody who earns less than $\$ 250,000$. So if you are not going to tax the average American, where are you going to get your money? The House wants to tax wealthy Americans and that's fair, they probably can afford it. So there is going to be an income tax surcharge on high-income individuals (of course, nobody is high-income; we are all middle-income).

High-income is defined as a single person earning more than half a million or a family more than a million. High earners will have to pay a higher income tax on their incomes above the half-million or million dollar levels - a 5.4\% additional tax. In addition, there'll be a sales tax on medical devices under the House bill.

Raising the income tax is controversial, so the Senate is going to just raise the Medicare tax a little bit for high-income persons, and then the Senate is going to tax high-cost healthcare plans. We've got a tax exemption for healthcare insurance that encourages people to purchase too much insurance. And so, if you have a "Cadillac" plan (a gold-plated plan), you'll pay a tax, and that will discourage people from having these excessive, goldplated plans. The unions don't like the tax because they've negotiated some of these gold-plated plans for their workers--that's why the ax is controversial. Under the Senate bill, there'll be a tax on elective cosmetic surgery. There also will be new fees on drug companies, device companies and insurers, because nobody likes drug companies, device companies and insurers. These businesses are easy to tax--unless their lobbyists object too much.

All of this is going to generate a fair amount of money, but not enough. So where else can we get money? We can cut Medicare spending by $\$ 400$ billion over ten years. How do we do that? Well, we reduce reimbursement rates to health-care providers; doctors get less money, hospitals get less money. Let's remember, Congress periodically says they are going to do that, but every time, they suspend the reimbursement cuts. Now and then, they have reduced reimbursement rates, but will they really sustain $\$ 400$ billion in cuts? That's a good question. 
Medicare Advantage is the private Medicare option. You can go into the traditional Medicare plan in which the government pays the bills, or you can subscribe to a private health plan, and Medicare will pay your premium. $20 \%$ of Medicare recipients do that, and it actually costs more than traditional Medicare. So it's time to cut that back, and that's part of the proposal.

In sum, there are several big concerns. You are asking people who earn $\$ 60,000$ to spend $\$ 6600$ toward insurance. Can they do that? That's after subsidies. So a lot people aren't going to be covered. Will the subsidies keep up over time. Will Congress really year-after-year vote appropriations for lower-income people for their subsidies? Will Congress stick to the Medicare plan cuts? Will all of this survive the next few years? It's great to expand access, but that's not going to happen until 2013 or 2014. Will Congress maintain this legislation until it kicks in three or four years from now. If we continue to have trillion dollar budget deficits, and we have wars to fund, who knows?

And then what about the strategy of expanding access now, deal with the costs later?, It's much easier to expand access--the voters love that--but try to ask them to cut costs. We saw the HMO backlash in the 1990's. HMO's were really good at cutting costs without sacrificing quality. But people didn't like the limits on coverage, even though they were good limits. Even though they weren't being harmed by the limits, they didn't like them.

And so, we are not going to try cutting costs right now. We'll expand access and deal with costs later. But that doesn't always work, because it tends to unravel over time and become unaffordable. That was what happened when Oregon expanded access to healthcare. They tried it, and it worked for a few years until state ran out of money. It worked because they had a boom in the economy. When the economy turned, the state couldn't afford to pay for the expanded access and their level of uninsureds is as high as it was when they started. So who knows. But as President Obama said, sticking with the status quo is even worse.

MR. FOER: Thank you, David. Question: How many people out there think they could explain what the McCarran-Ferguson Act is? Just raise your hand. Okay, it looks like Chris has his hands full. Go ahead and explain.

PROFESSOR SAGERS: I will do my best and I will actually try to keep it brief. I'm very pleased to say first of all that I have Kaiser Permanente Insurance and it rocks. So yahoo! Kaiser!

After those two very broad presentations I am going to give a very, 
very narrow one. It's one that's directly relevant to the topic that we proposed today and the topic that we talked about during what was really a great session this morning. That topic was: what should be the role of antitrust in reforming or improving our healthcare system?

The reason that McCarran-Ferguson repeal is relevant is that the business of insurance since 1945 has been to a certain extent exempt from antitrust.

To make a long story short, antitrust is the federal law in the United States that requires that businesses compete with each other and not collude or try to avoid the effects of competition.

Well, we have had a federal statute - the McCarran-Ferguson Act -for about 60 years that has said antitrust doesn't apply to insurance. Instead, insurance companies are subject to regulation by the state governments. And to some extent the state governments do enforce competition values, although I think most observers believe they recognize them in name only and don't really enforce them.

By-and-large there doesn't seem to be much doubt that in health insurance we don't have a competitive marketplace at all. Health insurance markets are local, and most local markets throughout the United States reflect some degree of concentration, quite a lot of them severely so. Concentration in this context means that there aren't very many sellers of insurance in a given market. When there aren't very many sellers you likely don't have much competition, which means you don't have much effort to lower prices or reduce costs.

Well, efforts to repeal the McCarran-Ferguson Act go back now about 20 years, and once again there is a repeal effort, which has been seen all along as part of healthcare reform. The bills that have been pending this year to repeal the McCarran-Ferguson would apply only to health insurers and to medical malpractice insurers. I guess that superficially makes a certain amount of sense, because those are the two insurance markets most relevant to the cost of healthcare, or so one might think.

Apparently for reasons of political expediency more than anything else, this year's bills would repeal the McCarran-Ferguson immunity only as to certain kinds of conduct. In other words, the bills wouldn't say the McCarran-Ferguson Act is hereby repealed as to the business of health and medical malpractice insurance. Instead, it says the immunity is repealed, and I am quoting here, with respect to "price fixing, bid rigging and market allocation". Those are antitrust terms of art. To make them simple, price fixing is conduct in which two competitors get together and say, okay, we 
won't sell our product for less than so and so. Market allocation is the really fairly similar sort of arrangement in which competitors say, okay, you get Toledo; I'll take Cleveland. And as for bid rigging -- I don't even know what they were thinking with bid rigging. It's really just a variety of price fixing.

Anyway, the state of play right now is that the these were introduced to repeal McCarran were introduced as freestanding bills, but all along it was clear that there would be an effort to make them part of the overall health reform effort. Indeed, the House McCarran-Ferguson repealer was incorporated by Speaker Pelosi by Manager's Amendment in the House healthcare bill, which passed the House in early November.

The Senate version of that same bill hasn't yet been included in the Senate health bill. However, Senator Leahy, who sponsored, intends to add it by floor amendment.

But it's really much less likely that repeal will be included in the final Senate bill. We've heard a lot about the three moderates in the Senate who have opposed the leadership bill. One of them is Senator Nelson of Nebraska. He is formerly a State Insurance Commissioner and an Insurance Executive and he opposes McCarran repeal, and it seems likely that he will manage to keep it out of the ultimate bill. Whatever hope McCarran repeal ultimately has lies only with the conferees, who might try to include it in a conference bill.

So that's the state of play. But the real question that I was asked as part of this conference was, assuming some version of McCarran repeal is adopted, what will be its consequences? In a sense, my answer must beg a $\$ 64$ question.

I think Barak Richman correctly identified it already: conceding that health insurance is not competitive, would it actually make that much difference merely to expose it to competition?

I don't think anybody can really say how much impact competition would have. There is an argument that it wouldn't have that much impact, mainly because insurers can enter a new marketplace only if they can establish relationships with the existing network of providers in that area, and that's believed to be very difficult at least under current circumstances.

So even if the risk of antitrust liability were made much more meaningful, in health insurance it would at least take a while for robust competition to break out. Now, I personally believe that McCarran simply must be repealed, it has no justification and it does have bad consequences, but for 
what it's worth even I think that it would be only a necessary, and not a sufficient, solution.

Even aside from that uncertainty, predicting the consequences necessarily raises two other questions. First, these bills join medical malpractice and health insurance in the same policy instrument. While that makes a certain superficial sense, the two markets are really quite different. Medical malpractice insurance is a so-called "Property-Casualty" product, which means that it insures people against the risk of liability to third parties. So if a doctor hurt somebody negligently, Medical malpractice insurance will indemnify the doctor.

Health insurance is not property-casualty insurance. It's quite different. Part of our discussion earlier today concerned the fact that health insurance arguably isn't insurance at all, or at least most health insurance is pretty different.

The problem in genuine property-casualty markets is that it's very hard to anticipate how much a company must charge in premiums today to ensure solvency when significant losses come down the road. Indeed, all observers of these markets acknowledge that there is a problem in propertycasualty markets, which goes by the name "insurance cycle" or "underwriting cycle". Periodically pretty much all the insurers in the market will realize, boy, our premiums are kind of too low right now to ensure our longterm solvency, so we've got to really, really jack up our rates to make sure we don't go under. That's a recurrent problem.

The only point for my purpose is that the existence and the persistent lack of any persuasive explanation for the insurance cycle is a problem in medical malpractice insurance. It's arguably relevant to whether antitrust immunity is needed. Personally, I don't think it's a very good argument, but it's one that's being made.

The other problem, which is a significant one and is frankly much too thorny to really dig into in this setting, is that the McCarran repeal bills would not repeal the immunity entirely, even as to health and medical malpractice insurers. As I said, the repeal would be limited to specified conduct like price-fixing.

So health insurers and medical malpractice insurers would still be immune from antitrust for conduct other than price-fixing or market allocation, so long as that conduct is also within the remaining vestiges of the McCarran-Ferguson immunity. Now that long sentence, I think, gives some flavor of just how complicated this problem really is. To know whether conduct would be immune following this repeal, one would first have to ask 
whether the conduct price-fixing, bid-rigging or market allocation. If not then the question is whether it would be immune under the existing law of McCarran immunity? That is, is it the "business of insurance," and is it regulated by the states?

In other words, it's a really complicated mess. And even within that complicated mess, to make matters worse, the case-law that exists under the McCarran-Ferguson Act was already messy. Nobody really knows exactly what, for example, is included within the statutory term the "business of insurance". Does it cover price-fixing, for example? Sometimes yes, sometimes no.

Anyway, to sum up a very complicated problem, even if the repeal bills were adopted they likely will have some sort of limitation to specified conduct like price fixing. The repeal will not apply to some conduct that might be bad. So even if the repeal goes through, insurers might still be able to be to do those bad things.

The flip-side of that same coin is, some types of conduct that the repeal actually would apply to are in many cases already illegal. The McCarran-Ferguson Act doesn't apply to everything - it shields insurers from antitrust only when they engage in conduct that is "the business of insurance" and it is regulated by state law. So there is sort of a double problem in the repeal that we are likely to get: it won't expose some genuinely bad conduct to antitrust liability. On the other hand, it will make antitrust liability available to some conduct that's already illegal and therefore already nominally discouraged by the law.

Still, having said all that, I just want to say a couple of things about why even a limited McCarran repeal might still be a good thing.

First, there may be important long-term effects. In the future, if markets become more competitive, then some types of conduct might start to arise that will be open to antitrust liability under this repealer.

Second, there is a certain psychological value to repealing McCarranFerguson. Among other things, when Congress says that specified conduct is now illegal, it is a pretty strong message to the Justice Department or the Federal Trade Commission to actually do something.

And finally, a very technical point. There is also language in the House health bill that would correct limitations on the power of the Federal Trade Commission, which I think could be very valuable. Specifically, the Federal Trade Commission would be empowered to investigate the insurance industry, including but not limited to antitrust enforcement. but also 
beyond the antitrust enforcement. That is work the Federal Trade Commission hasn't been allowed to do for about the last 30 years, and it could be extremely valuable.

MR. FOER: Okay, thank you Chris. We are going to change signals a bit at the line of scrimmage here. David Balto's airplane is leaving a little bit late so that gives us an opportunity to insert him into the wide end position and send him downfield with -- if you take too much time the plane is going to leave. So speak to us.

MR. BALTO: Thanks, Bert. This is really a heady end time for all of us antitrust nerds. We are like the kind of people who are at the dinner party, just waiting for somebody to ask us about competition or consumer protection and nobody ever does. But we sit there quietly and politely.

This is a fabulous time in Washington for antitrust nerds, because every day we hear Congressmen talk about the key to healthcare reform is competition. We couldn't be happier. I mean it's sort of like being an Indiana Ice fan. Are there any Indiana Ice fans here? So you don't even know about the minor league hockey team. And all of a sudden they win the USHL Championship.

The problem is that we really have what is the most ragtag structure. First of all, let's get the basics down. Competition and consumer protection, enforcement is important, because we want markets to work effectively. And there are basically -- no one has so far has disagreed with me on this diverse panel -- but there are three things you need for markets to work.

You need choices because you want to have alternatives to play people off against each other. You need transparency; you need to know what you are buying and what the terms and conditions are. And then especially when we are dealing with intermediary markets, we want to make sure we've got honest brokers. We want to make sure there are not conflicts of interest, that people really do represent your interests. And, by any measure, and I am just going to stick with health insurance, this market is broken.

In terms of choice, all studies seem to point to the fact that most markets are extraordinarily concentrated with a large number of states being dominated by a single insurance company. In terms of transparency, good luck! Read your insurance policy, have your employer who purchases the insurance read your insurance policy. These things are inordinately complex. Consumers really don't know what they are getting. There is really a lack of transparency. 
And finally in terms of conflicts of interests, insurance companies don't necessarily act in the interests of consumers, and brokers who are hired don't necessarily act in the interests of the employers who hire them. What is the result? Well, President Obama, in a seminal statement to the American Antitrust Institute, when he had to identify one market that was not working competitively, it was the health insurance market. And he pointed the finger at the Antitrust Division of the Department of Justice, which in the past eight years has allowed a tsunami of mergers. Over 400 mergers in the past eight years, which has led to this tremendous degree of concentration.

Of those 400 mergers, how many did the department say no to? They just asked in a couple for a minor restructuring. So they basically let mergers proceed at will. And the story isn't much better in terms of going after anticompetitive conduct against health insurers. Chris has told you about an antitrust exemption. That's where Congress says, don't worry, you live in an enforcement-free zone, collude at will, and stuff like that.

Well, there is another way to grant exemptions to industries and that's by having lazy or misguided antitrust enforcers. And basically, over the last eight years, the antitrust enforcers brought zero actions against anticompetitive conduct by health insurers, zero actions against fraudulent or deceptive conduct by health insurers. Zero.

The FTC, for example, spends all of its health consumer protection resources going after those fraudulent advertisers who tell you that if you take this pill, you'll lose 20 pounds over the next week. That's where they spend their time, protecting those people who are easily duped.

So what's the result of this total lack of enforcement? In the past eight years, the number of uninsured have increased from about 38 million to well over 47 million. The profits of the major for-profit insurance companies have skyrocketed from about $\$ 3$ billion a year to over $\$ 13$ billion a year and premiums have similarly skyrocketed. This is an industry that is out of control by any measure.

Hopefully the attention that has been given to the fraudulent and egregious conduct by health insurers will somehow filter down. The distance between the Capitol, the Senate, the House and the Federal Trade Commission is six blocks. It's only another three blocks to the Antitrust Division of the Department of Justice. And I think they might have TVs there. They might have watched the Congressional hearings that are going on. Hopefully that will filter down to these antitrust and consumer protection enforcers.

What would we hope to see from a reinvigorated antitrust and con- 
sumer protection enforcement from the Antitrust Division at the Department of Justice? First they have to learn that famous two letter word that Nancy Reagan tried to teach us. 'NO'.

The next big health insurance merger that comes along, the antitrust division should just say no. And in terms of mergers that have occurred in the past that may be anticompetitive, it's time to see what happened and see whether or not consumers have really benefited, and by the way you do get two or three bites at the apple when you are an antitrust enforcer. You can go and correct your mistakes. It's like being Catholic. So they can go back and try to rescind consummated health insurance mergers.

Second, they've got to realize that the consumer protection laws actually do apply the health insurance industry. Now there is a little thing here. Other people on the panel may say that the state insurance commissioners are responsible for consumer protection enforcement and indeed states have these statutes. The problem is, states don't have resources and we did a study that found that basically over one third of all states have never brought a single consumer protection action against fraudulent or deceptive activity by health insurance companies and something like $95 \%$ of the actions were brought by just four states.

If you want to have health insurance protection move to New York, move to California. Otherwise, good luck. In many states, the insurance commissioner has 50 million other things to do and doesn't have time to make sure that those laws are properly enforced. So hopefully the FTC will step into this gap and go and start having meaningful enforcement against deceptive actions -- not only against those people who sell you those pills for which you'll lose 20 pounds by just taking them but also against egregious conduct by health insurers.

Third, the FTC has the secret weapon. It's called Section 5 of the FTC Act. The simple Sherman Act prohibits relatively straightforward but limited types of conduct. Section 5 of the FTC Act prohibits things that are unfair trade practices. The FTC should learn to use that statute to go after some of these egregious and deceptive practices.

Hopefully, that six-block or nine-block distance between Congress and the two enforcement agencies isn't too big of a gap to bridge and those agencies will pick up with an activist enforcement agenda against health insurance companies after a health insurance reform is passed.

MR. FOER: Okay, thank you David, now you can catch your flight. This brings Tim Greaney to bat. 
PROFESSOR GREANEY: Before David leaves, let me agree with him on one important thing: antitrust enforcement has gone straight downhill since I left the Justice Department and since he left the FTC,(and since Bert left the FTC as well). So he is definitely right on that score.

Okay, let me go off message for a minute because I think some of the introductory remarks about the health reform sounded pretty pessimistic. I certainly have a lot of criticisms and have disagreements with a lot of what's going on, but let me just throw out a few reminders about why we're here.

You've heard the numbers. Our health care cost is two times that of the OECD countries; the only country in the developed world without full insurance for its citizens; ranked $37^{\text {th }}$ by the World Health Organization, which uses various measures, but you really dissect quality, one sees we are very low on many important quality measures. Sure, we're good on some high-end cancer treatments but we are way down the list on preventable illnesses, newborn care and all sorts of routine healthcare quality metrics.

So let's remember there is a lot to be done. About financing comprehensive reform, first of all remember, the CBO projection concludes that reform will reduce the deficit over ten years. I repeat, reduce the deficit.

Now there are taxes proposed to pay for reform The House bill relies on a more progressive tax mechanism, a policy I would have thought would have some popular and common sense appeal. If Congress repealed the Bush tax cuts for the top $1 \%$, top $1 \%$ of the country, that would pay for something like three-quarters of the ten year cost of the Obama healthcare plan. And if you remove all of the Bush tax cuts you'd be paying for twoand-a-half times the cost of the healthcare legislation,.

So I think, flawed as reform is in some respects, doing nothing is not an option and I think the unimpeached projections about future costs suggest we are in real trouble if we don't move forward.

I think there are very important potential cost-saving provisions in the legislation, reforms that $\mathrm{CBO}$ can't measure because of uncertainties about the form these new programs will take and how they work. Although CBO chooses not to measure some of them, they constitute a very important redirection of Medicare payment policies that hold out the hope of really changing the way healthcare is delivered.

And on top of that, remember, there is massive investment going on in infrastructure through this bill and the Stimulus Bill. My State Missouri is getting $\$ 2$ billion towards improving information technology and related 
improvements.

There is a lot of money going into education, training alternative care providers, doing a lot of the things we haven't been doing for the last 20 years. A lot of that is hard to measure: how it will be implemented, how much it will save? But there are real savings there. So although some of the pessimism out there is justified, I think these reforms are absolutely necessary.

So my assigned task was to talk about competition as it affects providers, hospitals, doctors and device manufacturers, and relate that to antitrust. The first message I want deliver is that competition does matter. It matters with regard to basic the structure of this reform proposal, and it does matter in the marketplace, as we do have evidence that the competition has lowered cost.

Studies of hospital mergers have shown that these mergers have raised costs from $5-40 \%$ in the markets in which they occurred. We also have evidence that more competition can promote greater diversity of options, that physician competition can result in lower costs, and that we can have real benefits from competition.

One of the reasons competition matters is because when you have markets that are concentrated -- i.e., you only have a few providers of a health care service in town -- they tend to raise prices. And we've seen over time, especially in the last ten years, some very dramatic increases in concentration, particularly in the hospital market --where my alma-mater the Antitrust Division of the Justice Department was, as David suggested, asleep at the switch, it's also apparent were also asleep at the switch in other areas, as not a single physician merger has ever been challenged.

Now there is what may appear to be a paradox when we talk about concentration in health care delivery. You have pockets where there is very little competition, i.e., acute care hospital markets, and many specialized specialty physician markets; for example, cardiology and orthopedics services in many markets are highly concentrated.

At the same time, you have remarkable fragmentation. In most markets, primary care physicians are practicing in solo or very small groups, and health care delivery is fragmented in the sense that there's very little care coordination, which is especially important in treating chronic diseases.

So we have the worst of both worlds. We see large pockets of concentration around the country, and at the same time we have fragmentation so 
patients don't get the kind of care delivery that would promote higher quality care. As to integration of the kind that Barak spoke about, "vertical integration" in antitrust parlance, linking hospitals, to physicians, to nurses, to alternative care providers, to social workers: that kind of linkage is absolutely essential to making competition work, especially with respect to making bundled payments. That is, insurers compensate providers by making payments to a single entity, saying "you distribute that money, allocate that payment among your providers, among your hospitals, specialized physicians, nurses, social workers, but do it in a way that provides high quality, cost effective care."

Essentially these entities, which the reform legislation calls Accountable Care Organizations, will pay people to take histories on care, pay nurses and others to call people to make sure they are taking their meds, etcetera, all things the systems fails to do now. That distribution system is essential to have not only higher quality care, but also cost-effective delivery of care.

So the bottom-line message of what we talked about this morning and the writing some of us are doing is that you do have fundamental structural problems in the market that need to be dealt with in order to help competition succeed.

Admittedly we encounter a real world problem when it comes to provider market structures because, to some extent, the horse is out of the barn. Some of the pockets of local provider monopolies are there to stay. But we can do some things to encourage development of new competition, sometimes specialty hospitals will develop, we can promote new entry by physicians, new physician groups forming and there is a strong case for removing regulatory entry barriers.

Antitrust law certainly will have a role in the future both in guarding against future concentration, increases of concentration through mergers, and dealing with abuses of monopoly power.

For example, one problem that arises in many markets is that the entity with market power can exclude others. And frankly, the case law that has developed through the courts has not been favorable to these cases. The optimists among us hope that a more vigorous DOJ Antitrust Division and FTC might result in better case law developing.

As I mentioned before, there are things that I think the legislation is doing that can encourage providers to reorganize markets. These are among the most important-and overlooked--features of the Senate bill--changes that will both encourage and subsidize through efficient payments, the development of new organizations. such as Accountable Care Organizations 
and Medical Homes.

These innovations are going to take some time to develop but the legislation would establish Medicare pilot programs which can be turned very quickly into system-wide programs. So that's an important development to watch.

Finally, I'll just offer a few thoughts about developments in the competition law world. Those of you who follow antitrust probably know that there is an important case in the Supreme Court right now, the American Needle case. AAI has written a very important brief in that case, because it is the kind of case that could change antitrust law very dramatically. We don't know which way that will go, but it is important in health care that antitrust law not retreat from recognizing that joint ventures among independent competitors should not get a free pass unless there strong procompetitive benefits flowing from the venture.

Continued competition advocacy by DOJ and FTC, before Federal and State health regulatory agencies is important to keep them on the ball and keep them enforcing the law. And, as David said, there are other areas where the government has been very successful, and that has brought many important cases.

One of the most notable is in the pharmaceutical area, where the FTC has challenged so-called reverse payments by major pharmaceutical companies. Basically, what that involved is the practice of many brand-name, patented drugs, essentially, paying off generic companies to get them to stay out of their market.

The numbers are staggering as to how much this is cost to the consumers. I think David mentioned earlier the FTC estimates are that the cost of these payments is $\$ 3.5$ billion per year -- that's how much extra consumers extra are paying for drugs, because the brand name drugs have kept out generic competition.

There is an ongoing dispute right now about what antitrust standards should apply to these practices, as several Circuit Courts have given different interpretations. Legislation is pending in Congress to put in place a clearer (and more stringent) standard. The FTC is to be commended for its leadership in this area.

Finally, David didn't get a chance to talk about it, but many of his complaints against the insurance industry are at bottom consumer protection issues, and those are topics that both State and Federal enforcement efforts should be directed at -- just egregious abuses persist out there that can be 
tackled under insurance, fraud, consumer protection and other laws. . I'll leave it at that and I am sure we have time for questions.

MR. FOER: Yeah, we have and we do and let me ask Gayle if she would like to say anything about the reverse payments issues that just came up or anything else. Reverse payments is one of the most important developments in the last 20 years in antitrust.

MS. REINDL: Well, it is. And the Federal Trade Commission, to give them a few little feathers in their cap, actually has been active in this area and has challenged several of these, what the FTC calls "Pay for Delay" settlements. This is where the patent holder with the brand-name drug, instead of litigating to the end, just pays the generic competitor to stay out of the market for a long period of time.

The patent-holder keeps the monopoly, the generic competitor gets some of the monopoly profits and the two drug companies are happy, but consumers end up paying, the FTC estimates, $\$ 3.5$ billion a year more than they would pay if the generics were made available. So the FTC has brought cases challenging those settlements. The problem is the courts are inconsistent. Some of the courts have rejected the FTC's challenge to the settlements. So, legislation being considered in Congress would make it clear that this sort of a pay-for-delay or reverse payment settlement breaks the law.

MR. LONDON: Well, since we are talking about generic drugs in a sense, let me just make the short point that there are success areas for competition even without new legislation.

Generic drugs are now something like $70 \%$ of the prescriptions that are written and actually last year, the total cost of generics even though the percentage -- the prescriptions rose, we spent almost $3 \%$ less. So I think Chris said earlier, we have some questions about competition. I don't really have any questions. I'm sure if we had the kind of competition we'd all like here, all through this healthcare system, you'd get the kind of results you're beginning to get in the prescription drug market. I think there is more to come because the business model in prescription drugs is being changed by mail-order, it's being changed by Wal-Mart and Target and some of the grocery chains, who were cutting prices very sharply on some of the older generics which are very effective.

So I think competition in the drug arena is the proof of what competition could do in the health area if it really began to work.

PROFESSOR COMANOR: The beauty about this panel is that eve- 
rybody takes a different view on every topic. And so I don't understand what the audience is making of it. So I want to go on a rather different tack, because of course what we're really concerned with is healthcare much more than health insurance.

And sometimes we confuse the notion of health insurance with the notion of healthcare, and those are really different things, especially since insurance in this country isn't really insurance at all. Insurance deals with payments for very unlikely events, like your house burning down, or your being involved in an auto accident. But we all know that we are going to need healthcare in the course of the year or most all of us. So except for major medical issues, what we currently call health insurance isn't health insurance at all, it's pre-paid payments for health care, so that our expected payments are made by some third-party rather than ourselves.

Well, you might say, but my employer pays for it, so I don't have to pay for it; isn't that the same thing? The answer is yes, because we know that from the employer's point of view, it's the total cost of the employee that matters, which includes wages plus benefits, and the most important benefit of course is health insurance.

So if the employer doesn't pay health insurance for you, you would receive higher wages, because that's the amount the employer is willing to pay for your services. So each of us pays for our health insurance in the form of lower cash wages. What's the advantage of having our healthcare paid in this indirect way?

Well, back in 1945, really is an afterthought during the Second World War, the Congress made a rather strange decision which we are stuck with. It said that health insurance and other benefits would be deductible for the employer but not taxable for the employee.

So the reason why we like this insurance façade, and it really is a façade, is because we're paying for our healthcare with before tax dollars, while we pay for everything else with after-tax dollars. Indeed, the largest aberration of the current system is this strange tax subsidy which came to us as an afterthought during the Second World War.

Currently, a large share of the problems we face with health insurance are due to the rather bizarre way that we finance healthcare through the employment contract. If you think about it, there is no essential reason why healthcare should be financed through the employment contract.

But, we do it because of this afterthought of 50-plus years ago, and that's what we should be avoiding rather than the type of reform that we see 
now. We've seen in recent years increasing numbers of uninsured people.

And I thought of that as a plus, because this was the means by which the existing system would go away, it was self-destructing. So what did the Obama plan do? It seeks to prop up the existing system of prepaid healthcare which is called Health Insurance but which isn't Health Insurance at all.

Now, I surely agree with my panel members that it's better than doing nothing. It's certainly better than doing nothing. But we had a chance to make a clear reform effort in the way we finance healthcare, to bring us back in accord with the levels of expenses commensurate with other countries in the world, and we chose not to do it, and that I think is the great failure of the current healthcare reform plan.

MR. FOER: When you refer to bringing us back to expenses commensurate with the rest of the world, Bill, I take it you're referring to the expenses that are incorporated into the price of products that we are selling in the international market?

PROFESSOR COMANOR: No, what I was really talking about is the fact that we spend $15-16 \%$ of our gross domestic product on healthcare, while most of the other developed countries spend on the order of $10-11 \%$. That's a big difference.

MR. FOER: Make my point as an additional point then, which I think is that there is a serious implication of that unthinking choice Bill is referring to that puts us in a bad position worldwide. Let me turn to Joe Bauer.

PROFESSOR BAUER: Thanks Bert, and I really want to thank both the IU Indianapolis School of Law and in particular Max Huffman for arranging this conference. It has been terrific. I hope it's been fascinating for you, but it has certainly been fascinating for us here on the panel who have been here since 9:30 a.m. and really had the opportunity to become educated about a lot of these very, very important issues.

I wanted first to talk briefly about something that Chris was talking about the McCarran-Ferguson Act. Chris didn't go through the long, extensive, and perhaps not overly interesting history of the McCarran-Ferguson Act. But, McCarran-Ferguson was passed in 1945 in an attempt to restore the balance between State and Federal regulation of the insurance industry.

It had long been assumed in the United States by the courts and otherwise that insurance was a local enterprise and therefore would be regulated only by the states. The Supreme Court decided a case called 
Southeastern Underwriters which really upset that understanding, and in almost record time -- I think it was less than two months -- a bill called the McCarran-Ferguson Act was passed by both Houses of Congress and signed by President Roosevelt, one of his last acts before his death the following month. And what McCarran-Ferguson provides as Chris said was not a complete exemption for insurance companies, but an exemption for the so-called business of insurance, and that term, what that really encompasses or does not encompass has been the subject of much uncertainty for over half a century.

McCarran-Ferguson also says that in order to be subject to that exemption that the activity has to be regulated by the states. Probably one of the saddest parts of McCarran-Ferguson is that the amount of regulation by the states necessary to enjoy that exemption has been minimal.

So I think I come to the same conclusion as Chris and others on the panel. At the end of the day, we probably would be better off if McCarranFerguson were repealed, although, again like Chris, I don't hold out a lot of hope that it would have substantial effects on the level of competition among providers of the components of health insurance, including medical malpractice insurance.

I do think it's important to understand that there are at least two things that insurance companies do under the umbrella of McCarran-Ferguson which at least might be important to maintain. One is certain kinds of information exchanges, and the other is standardization of the terms of insurance policies.

There are at least some arguments to be made that allowing insurance companies to do that allows them to achieve certain efficiencies. Those efficiencies include reduction of costs and better understanding by customers of what the terms of the insurance would be. Therefore, we need to be a little careful if there were a complete repeal of McCarran-Ferguson, including with respect to the health sector, and thus insurance companies were no longer allowed to engage in any joint activities, that we don't lose some of those benefits as well.

If I could talk briefly about what David Orentlicher and Tim Greaney were talking about. David properly reminds us that the Healthcare Reform Bill -- I was going to say that's sailing through the Congress, but this is sailing at glacial speed -- principally addresses the access side of the equation, but does little right now with respect to the reduction of costs. Since my knowledge of this debate is on the antitrust side, I just want to say that it is with respect to the cost side, rather than the access side, that antitrust has something to contribute. 
Across the spectrum of antitrust scholars -- from people who are more expansionists like myself, or folks who take a more restrictive approach -there is at least a acceptance across the board that what antitrust should be doing is maximizing consumer welfare, that means, among other things, lower prices, better products, more efficiency, greater choice and so on.

As I noted, it is with respect to the cost-reduction side that antitrust has something to contribute, because the premise is the principal way one gets advanced consumer welfare is through enhanced competition.

Barak properly says that those consumer benefits would occur if we had more competition, both on the provider side and on the consumer side. However, if we only have more competition on one side, we really have a second-best here. In that case, we really may not advance consumer welfare.

From the antitrust side, the focus needs to be on what can enhance competition, increase competition - and also consumer welfare. Again, we must be mindful of what Barak says -- that sometimes more is not necessarily better.

MR. FOER: I think there are two terms that we haven't elucidated sufficiently before we get to audience questions, and I think David has got a question for the panel as well. But, let me ask for some elucidation, David. We hear about the exchange and the importance of an exchange. Would you just spell out what that is, and the other question I'll throw to Barak perhaps, is the public option.

We hear about the public option, it maybe off the table now, but I think we should still just say what it is and maybe give a hint as to its competitive implications.

PROFESSOR ORENTLICHER: Yeah, sure. The idea of the exchange is, we are going to expand access by creating the ability for more people to purchase insurance who don't have it now either because their employer doesn't provide it or they can't afford it on their own, but where will they buy their insurance?

What will happen is this exchange will be created, the government will oversee it, and health care insurers can apply to offer an option in the exchange for these new individuals who now can afford coverage. Insurance will be more affordable for people who now are discriminated against because of their pre-existing conditions, because there will be subsidies for people of limited means, because small employers that would like to offer health insurance now will have the ability to buy in, because they too will 
have subsidies.

Once we've created this new population of purchasers, where will they go to buy? They'll go into the exchange. The government will set it up and identify different levels of coverage based on how generous the benefits are and how much of the costs are covered by the premiums and how much are left to cover out of co-payments and deductibles. So the exchange will rate the policies for different levels of quality, and costs, and people can go in and shop and they can either buy a basic policy with minimal benefits and minimal costs, or they can go to higher benefits-higher costs plans, whichever fits them best.

And the hope is that the government can make it easier, because right now how do you go out and negotiate for a plan by yourself? So the government will set up this marketplace where you can buy, so you don't have to go out and hunt down insurers and figure out what they have to offer. Then you can compare, because the government will structure it in a way that it's easy to compare the plans and generate a more competitive situation.

QUESTIONER: How do we know that the insurance companies will opt in to the exchange?

PROFESSOR ORENTLICHER: Well, this is one of the concerns. One of the worries is that they don't have to go into the exchanges if people can buy insurance outside the exchange. One of the problems we have is that sicker people have trouble getting insurance now. Well if the healthier populations buy outside the exchange and the exchange only services the people that are sick or who are a higher cost to insure, then we replicate the problem we have now.

The idea of reform is to treat everybody the same; no matter whether you are healthy or sick, you pay the same premium (but older people will pay more than younger people). If it turns out that the healthier people stay out of the exchange and the sicker people go into the exchange, then the exchange plans will have to charge more money and it will undermine the whole point of this effort to make healthcare more affordable.

So you are right, and that's one of the things that's being debated now.

QUESTIONER: Let me ask you though David, how realistic is that because you don't get a subsidy unless you are in the exchange and the subsidies go up to $400 \%$ of poverty. So does it that mean that the great bulk of the 30 million new insurers will be in the exchange? 
PROFESSOR ORENTLICHER: That's a good point. I suppose it depends on how generous are the subsidies. It's an interesting question, because if you are earning $\$ 60,000$, you are still expected to spend $\$ 6,000$ in the exchange toward your insurance. So if you take healthy people out of the exchange, can you price their insurance at less than $\$ 6,000$ ?

So, it does come down to the details, how generous the subsidies are, how much by having a younger healthier population you can reduce the cost. It's an interesting question.

PROFESSOR GREANEY: And remember the exchange actually does provide an important service for the insurance companies; it reduces greatly their search and administrative costs, the marketing, and eliminates the medical underwriting they do now, because they have to take all comers. So it does have a very important cost-lowering aspect by putting onestop shopping in place.

MR. FOER: It also provides the incentive for the insurance industry to be supportive of this whole reform effort, because it's going to bring them the potential of all these millions of new customers. I'll get to the audience in just a second. Let me ask Barak to crack the question of what is a public option and what's that all about?

PROFESSOR RICHMAN: Okay, now a public option is the euphemism created by the Democrats. In politics, there always is a debate over words. Just as there was a rhetorical debate over tax proposals -- is it an estate tax or is it a death tax? - how you describe the public option reveals how supportive you are of it. The Democrats obviously won this rhetorical debate since we all refer to the plan as a proposal for a public option. What was the Republican term? Was it the "government plan"?

\section{PROFESSOR SAGERS: Socialism.}

PROFESSOR RICHMAN: Ahh, socialism or communism. OK. So it's been observed that there are not enough insurance companies in the marketplace, there are not enough insurance options and that we have too little competition and too much monopoly. One proposed solution is to have add the government as one more player to the marketplace, to offer additional insurance plans that are operated by the government. The proposal is to offer these plans as additional options to insurance purchasers and add these offerings to the selections available at the exchange on the website.

Now exactly how that will be organized? Would it be a profitmaximizer the same way the insurance plans are? Would it cover the same amount as the private insurance plans? How will the price be determined? 
How politically insulated would it be? Who will make coverage determinations? All those are questions that really were never answered and maybe they'll never be answered if it really is off the table.

But it's really quite intriguing. We don't like monopolies in this country, but nobody ever suggests that government should come up with another operating system to compete with Microsoft. This is a very dramatic intervention, a radical solution to the lack of competition. Of course, the government has some experience being an insurer yet little experience designing operating systems, so the Microsoft analogy isn't quite apt. The government pays for a lot of healthcare even on the private side through additions to graduate medical education. So the government has some experience doing this, it also has some experience offering flood and crop insurance. The idea is that if the private market is so dysfunctional and if the private insurance companies are so untrustworthy, perhaps we should just have another economic player that happens to be operated and sponsored by the government.

MR. FOER: Let's go to the audience now and take your questions.

QUESTIONER: It seems to me this exchange is grossly overstated in terms of its possible benefit when you consider that every insurer in there has to comply with the state mandates. Indiana for instance has 65 mandates at the latest count. Every insurer is going to have to offer a plan that covers all that stuff. So the idea that there will be an option to get a stripped-down plan or a less inclusive plan is just misleading.

PROFESSOR GREANEY: There are some studies that suggest that the cost of the state mandates is not as great as portrayed. I think the Commonwealth Fund has study that suggests that the extent of state mandates which people often cite as adding to the cost of insurance, because many providers are mandated, certain diseases, coverages are mandated, is really no larger than those found in the Federal Employee Health Benefits plan. I'll get you the cite for that, because it's often discussed in this context-- I think it's in dispute as to how much mandates actually add to the total cost of insurance.

PROFESSOR RICHMAN: I might add that there is a lot of truth behind the question, which suggests that we are only going to have competition to the degree that the marketplace allows for competition. We cannot harness the benefits of competition quite as effectively if regulatory requirements restrict what insurers can offer. There are many political impulses on the state and federal level that we will have to restrain if we want to have low-cost and effective competition on insurance. 
PROFESSOR GREANEY: There is an article written several years ago by Russell Korobkin at UCLA which makes the case for mandates. These mandates didn't come out of thin air. They were voted in by your state legislators. His argument is that these laws correct a market imperfection -- we don't (and can't) bargain effectively for our insurance coverage, we don't carefully examine our policies to see if they cover drive-by deliveries and so on. So we do it through our legislature. Through our legislature we make the determination that certain services should be covered and the transaction costs of everybody trying to rewrite their insurance coverage to include these things is simply impractical and unrealistic. Korobkin makes an interesting market justification for mandates.

PROFESSOR RICHMAN: It's interesting who the "we" is though. When "we" go to our legislatures, often that "we" are the chiropractors and psychiatrists and the social workers who will lobby to have their services covered as well.

QUESTIONER: The US pays more per doctor and more per nurse than other countries and some economies parsed out the differential in cost for healthcare contributed to the higher cost per provider. And I was struck that all of the antitrust people don't look at either the AMA or the nursing association. An MD in most other countries is a three, four, or five-year undergraduate degree while the road to becoming a doctor in the US is much more strenuous. Similar constraints exist on the education and licensing of nurses.

So to me that's the big difference between the US and other countries. We have got a monopoly in MD creation and a monopoly in nursing creation.

PROFESSOR RICHMAN: You are correct, there are important regulatory constraints on physician assistants and other non-physician healthcare workers that restrict what they can do. Those limitations and other workforce regulations - especially those involving licensure requirements limit how much lower-cost workers can substitute for MD Care. And you're also correct that the AMA and other professional organizations have lobbied heavily to maintain those regulatory barriers.

Cross-national comparisons of the salaries paid to European doctors and American doctors, even those that adjust for the relative cost of education, find that US salaries significantly higher by nearly $60 \%$ even after adjustment. However, this is also a reimbursement problem, not just a problem about regulatory barriers and inadequate competition.

Moreover, notice that each medical student gets an enormous subsidy 
in his or her residency, as big as $\$ 500,000$. We also subsidize medical education through Medicare.

PROFESSOR ORENTLICHER: You are right, we do need to pay attention. And the problem is not so much how much we pay our doctors, but the way we pay them. Part of it is the disparity between specialists and primary care doctors. I think starting pharmacists earn more than starting pediatricians in Indiana, at least this was true a few years ago. A specialist makes two-three times that or more, depending on the specialty.

So part of it is, we encourage our new physicians to go into the specialties, rather than primary care. And then the fact that they are in a feefor-service system, rather than one based on salary or capitation. As many people have said, the most expensive medical device is the doctor's pen. It's all those unnecessary procedures and surgeries that are ordered because that's how doctors earn their salary. Actually, that it's not a salary is the problem in the way they earn their compensation.

So I think you could double primary care doctors' income and keep specialties at the same compensation, but if it was all salary I think healthcare cost would go down. In terms of some of the things that aren't being addressed in the health care bills, that to me is one of the most glaring things that's just not being addressed. We need to think about how we pay our doctors.

MR. FOER: The antitrust laws don't protect the hospital association or the nurse association, we do see cases being brought against the doctor cartels, David Balto would have loved to tell you why that's a waste of resources.

But you see those, there's actually some cases going right now, private cases, asking the question why are nurses -- why is there always a nursing shortage and yet nurses are underpaid?

And there are some cases asking that question and assuming that there is some hospital collusion going on there. I understand those cases aren't doing so well. But anyway the questions get asked, there is no exemption here. For a long time in antitrust history the professions were not really considered subject to the antitrust laws, and that changed in the 60 's and 70's, and professional ethics still get a great deal of credibility, but their examination is not exempt from the antitrust laws.

PROFESSOR SAGERS: I have a question along that line for David and Tim. Antitrust doesn't exempt those activities, and some cases are brought, but my sense is that there has evolved very quietly a case law for 
healthcare, and particularly for hospitals, that is in a lot of ways special. It's not a statutory exemption obviously, but it's arguably a judicial one. Does that address this problem at all? Hospital staffing decisions in particular are very, very hard to challenge under the antitrust laws.

PROFESSOR GREANEY: Right and, rightfully so actually because the great bulk of these staff privileges cases have nothing to do with competition. Typically these are challenges by physicians who have been denied staff privileges or who are thrown off the hospital's staff. There are hundreds and hundreds of these cases, and I have the misfortune to have read almost all of them. A friend of mine refers to these as the "junk food of antitrust," because there is far less there than meets the eye -- plaintiffs uniformly allege anti-competitive abuses: "I was thrown off the staff because they are afraid of me as a competitive threat", Ultimately the trial record reveals a fistfight in the O.R. between the doctor and somebody else, or bad medicine being practiced by the sanctioned doctor. The great majority of these cases deal with human foibles, but do not implicate competition. Interestingly, antitrust law has done a good job in weeding out these cases.

PROFESSOR SAGERS: Maybe one brought by the dismissed doctor, but the case law doesn't distinguish that fact. Importantly, a lot of Court of Appeals case law now holds that they are immune from Section 1 liability entirely.

So we have a case law developing that's also going to make it very hard for enforcement agencies to challenge, and I wonder if because of that case law that's why we don't see the agencies challenging these things. It must sometimes raise some concerns.

PROFESSOR GREANEY: You are right and for antitrust students out there, there is a lot of precedent that has developed, though not specifically on point to the kinds of issues we have discussed so far that has made antitrust cases very hard to bring in certain settings. Some obstacles include antitrust standing for private suits, what organizational form constitutes a single entity, and limitations on indirect purchaser suits. Most significant is a major Supreme Court case handed down just a couple years ago called Twombly that is of special importance to private litigation. The Court increased the requirements for pleading a case, to the point that a plaintiff has to have an awful lot of evidence to even bring a case, and that has pushed a lot of plaintiff's cases out the door. Other court decisions such as those that give short shrift to testimony by payers and others as to what the market is likely to happen, what is likely to happen in the market have an important influence on the outcome of fact-specific issues.

PROFESSOR HUFFMAN: What about the idea that by providing in- 
surance to the uninsured, we are shifting the demand curve to the right in substantial fashion. It's a whole bunch of new consumers in the system. Should we not expect to see costs rise dramatically as a result?

PROFESSOR RICHMAN: Recall that insurance is not a rival good. In other words, both of us -- you and I -- can be insured, yet when one of us enjoys that insurance we are not limiting the supply of insurance that the other can have. So an increase in demand does not necessarily lead to an increase in price, though of course it depends on who the additional insureds are.

What is interesting though is whether or not subsidizing health insurance will lead to an increase in consumption of healthcare services, which are rival goods. I personally think that it will lead to a significant increase in consumption, and this will lead to higher costs and likely higher prices for healthcare services. Some of my research addresses these issues of how insurance affects healthcare-seeking behavior. But a lot of people think that the uninsured are getting healthcare anyway, either through emergency rooms or through charity care, or through other sorts of different delivery systems that are less efficient than through the main channels. So some people characterize the expansion of insurance merely as a redirecting people who are already receiving health care to receive that care through more efficient means.

PARTICIPANT: The other thing to the extent there are the healthy uninsured who aren't buying it because they are not going to get their money's worth, and now you force them to buy insurance for which they won't get their money's worth, that helps reduce cost.

QUESTIONER: Two questions, I am not an expert, I am not a health insurance expert. A number of speakers have implied that there has been some egregious antitrust conduct by the insurance industry over the past eight years that should have been addressed. Can somebody explain what that is? And the second question is, if the issue is cost, should we also be talking about the amount of coverage? How many rounds of chemo, how many diagnostic tests do I get? My impression of most of it is patients wanting that $1 \%$ issue resolved.

PROFESSOR RICHMAN: I don't want to answer either question, but I want to put a remarkable irony that although you think you asked two questions, you really asked just one question, or at least both questions invite the same answer. It might be said that the insurance companies' egregious behavior - or the behavior that many suggest is egregious - is merely the conduct that you are suggesting that they should do in your second question, which is denying coverage for excessive treatment. 
Now, many suggest that sometimes insurance companies deny coverage in ways that amount to abuse. Sometimes they do that in ways that are misleading and rely on misrepresentations, sometimes they do that, I suppose - actually I don't know, but I suppose they could also do that through blatant antitrust violations. But what's interesting about your question is that it's really the same question. A lot of people are after the insurance companies for trying to restrain the very costs that you think they should restrain.

QUESTIONER: Well, I took antitrust law 35 years ago. Is the denial of coverage an antitrust violation in and of itself?

PROFESSOR GREANEY: Our most enthusiastic critic of the insurance industry has now left the building, but what he was pointing to were mostly in the merger area where there have been 400 mergers only a handful of government challenges.

Now of those 400 , the great majority of them did not present antitrust problems. So I have some questions about how many should have been challenged, but clearly some should have.

But David goes on to cite a long parade of horribles about insurance industry practices-- and they are horrible in many cases. Recissions of insurance policies based on a mistake or insignificant falsehood in applications for insurance, and gag clauses against physicians explaining their treatment decisions to patients, and all sorts of things. Those are generally not antitrust issues, they may be consumer protection issues, they maybe fraud, et cetera. And he makes the case that there should be more vigorous consumer protection actions. But the link between market competition and fraud is not that clear.

Final word, I have this problem with finger-pointing unless we point the finger everywhere, because there is a lot of abuse. Many of you may have seen 60 Minutes broadcast a few weeks ago with the incredible level of fraud -- perpetrated by providers in the Medicare system. That's being done by providers, not so much doctors, but lots of other providers, just outright theft.

There is also plenty of inadequate care, questionable billing ("upcoding") being done by hospitals as well. Finally, maybe we should do some finger pointing in the mirror: many consumers haven't demanded or won't accept any constraints on cost of their care whatsoever.

MR. FOER: I've got a partial answer also. In the McCarran reform there is an additional reform that wasn't mentioned which is that the FTC would be permitted to examine the insurance industry. Why is it not permit- 
ted?

Because last time they tried insurance industry lobbied through a law that said the FTC can no longer deal with that industry. Alright, well, if you can't deal with the industry and if they've got an exemption from private cases, a lot of things that maybe going or may not be going on are simply never going to be unearthed.

So we have a little bit of a transparency problem here in trying to answer your question.

PROFESSOR SAGERS: I agree with Bert completely. We don't know how much garden-variety antitrust violation there is in the insurance industry and we need to know. But because there has been partial immunity, we actually do know a little bit about conduct in this industry because insurers work a little less hard to keep their anticompetitive conduct a secret than most conspirators do. And there's plenty of evidence of garden-variety collusive conduct that doesn't involve things like denying coverage or just being nasty or fraudulent or whatever. And I can give some examples but we are running out of time.

PARTICIPANT: And in response to your point about doctors don't consciously order tests to make money and patients were demanding more care. But actually I think the reality is that doctors respond very quickly to incentives. So the doctor in the emergency room who gets paid a fixed amount per patient, orders fewer diagnostic tests than the doctor who gets a percentage of the patient payments for tests.

So doctors don't consciously think about their incentives, but they internalize their cost structure, their financial incentives. There is a famous study comparing British and US doctors probably 30 years ago now, where British doctors say, we give appropriate levels of care and American doctors give too much care. And American doctors say, we give appropriate levels of care and British doctors give too little care. They both internalized their financial incentives and thought they were practicing appropriately.

And I think that's true throughout medicine. And patients respond to a doctor's offer of care. The patients don't know what to ask for, but if the doctors offer something or if doctors are complaining because they are getting squeezed by managed care, that's what makes patients unhappy--when doctors feed them the complaints.

QUESTIONER: I think you referred to a case in the Supreme Court [called American Needle]? 
PROFESSOR RICHMAN: Actually it's a really neat case. The National Football League is a joint venture of 30 individual teams. These teams were all separate like the Colts. They are a single company. They maximize profits as a single company, but these 30 teams come together to cooperate in a number of different ways.

One of course is to schedule football games, develop common rules and playoff structures, and do all those things that are required to produce the games themselves. But they cooperate in a bunch of other ways as well. One way they decided to cooperate is to jointly market their logos for their sporting apparel. They thought, look, if we just hire one guy to do it for all 30 teams, we'd all make more money than if we'd each hire somebody individually.

So they got together, they issued an exclusive license to Reebok, and the person they didn't hire is American Needle. American Needle says, hey! You can't do that. This is a conspiracy. All 30 of you, you represent the entire marketplace for NFL sports logo, you're all colluding with each other and kicking me out as violation to the antitrust laws.

American Needle lost the trial, they lost at the appellate level, and then they appealed to the Supreme Court. The NFL said, hey, I've got an idea! Maybe by taking this to Supreme Court I can advance a certain argument that will get me out of Section One scrutiny forever. I want to tell the Supreme Court that even though we are 30 teams, we really are one entity, and as one entity we cannot collude, because you cannot collude with yourself.

So what this has become is really a two-issue appeal. One is, is the NFL a single entity, and therefore could never collude illegally?

And the second is, if they are not a single entity, is this a form of illegal collusion? And in disclosure, I've written a brief representing the NFL Coaches Association, which really felt strongly about that first issue. The second issue they didn't feel strongly about, and it's quite possible that the exclusive joint-licensing agreement is a pro-competitive collaboration. But what's problematic is that if this is a single entity that cannot illegally collude, that is, cooperation among its separate parts is akin to GM's divisions colluding with each other, then they can set limits on certain kinds of competition between the teams. Specifically, the league can permit the teams to collude on things like coaches salaries.

Now the reason this came up here is because we have lots of different participants in the medical community that cooperate in a whole bunch of ways. Doctors come together and create networks, hospitals come up with 
networks, and a lot of these collaborations you might say are fairly procompetitive. They come together, for example, to develop a common billing system. They come with electronic medical records, which is too expensive for any one doctor's practice to do but is possible when they all come together and cooperate.

But also they come together and collaborate in very anticompetitive ways, and the idea that Chris has advanced is, if American Needle gives the NFL teams wide latitude to collude, so much so that they actually get some kind of designation that they cannot illegally collude, then that could extend to lots of healthcare circles. Doctors who cooperate :- sometimes procompetitively and sometimes anti-competitively - might be beyond the reach of the law, and prosecutors or plaintiffs might not be able to challenge anticompetitive collusion.

MR. FOER: Depending on how the Supreme Court deals with this very complicated issue, it could give -- first of all it could revolutionize sports, all leagues could then become able to act as monopolists, and it could have spillover effects in all other industries. But it's tough case to figure out exactly how you say the different -- we want to encourage joint ventures, and collaborations on certain occasions, but we don't want them -- we don't want that ability to be overbroad and overused and undermine competition. 
